\title{
A review of intussusception cases involving failed pneumatic reduction and re-intussusception
}

\author{
Rahşan Özcan, M.D., ${ }^{1}$ Mirzaman Hüseynov, M.D., ${ }^{1}$ Şenol Emre, M.D., ${ }^{1}$ Çiğdem Tütüncü, M.D., ${ }^{2}$ \\ Hayriye Ertem Vehid, M.D., ${ }^{3}$ Sergülen Dervişoğlu, M.D., ${ }^{4}$ İbrahim Adaletli, M.D., ${ }^{5}$ \\ Sinan Celayir, M.D., ${ }^{1}$ Gonca Tekant, M.D. ${ }^{1}$
}

\begin{abstract}
${ }^{1}$ Department of Pediatric Surgery, İstanbul University Cerrahpaşa Faculty of Medicine, İstanbul-Turkey ${ }^{2}$ Department of Anesthesiology, İstanbul University Cerrahpaşa Faculty of Medicine, İstanbul-Turkey ${ }^{3}$ Department of Biostatistics, İstanbul University Cerrahpaşa Faculty of Medicine, İstanbul-Turkey ${ }^{4}$ Department of Pathology, İstanbul University Cerrahpaşa Faculty of Medicine, İstanbul-Turkey ${ }^{5}$ Department of Radiology, İstanbul University Cerrahpaşa Faculty of Medicine, İstanbul-Turkey
\end{abstract}

\begin{abstract}
BACKGROUND: The aim of the present study was to evaluate cases in which intussusception was unsuccessfully treated with pneumatic reduction (PR), and intussusception recurred following PR.

METHODS: The medical records of $40 \mathrm{I}$ patients who presented with intussusception between 2003 and 2014 were retrospectively analyzed. Included were $6 \mathrm{I}$ patients, 20 of whom underwent unsuccessful PR (Group I), and $4 \mathrm{I}$ of whom experienced intussusception recurrence following PR (Group 2). Treatment and outcome were summarized.

RESULTS: In Group I (mean age: 14.2 months; range: 2.5 months-6 years) surgery was indicated due to PR failure in I5 patients, and perforation occurred during PR in 5. In these 5 patients, age was under I year (range 6-9 months) and mean time to presentation was 3 days (range 2-4). During laparotomy, pathologies were noted: mesenteric lymphadenopathy (LAP) and/or Peyer's patch hyperplasia was observed in 15 cases, Meckel's diverticulum in 5 cases. In Group 2 (mean age: 20 months; range: 3 months-6 years), intussusception developed after successful PR in 4 I patients, most frequently within the first 24 hours (2I.5I\%). Of the 41 patients, recurrent intussusception (RI) was treated with PR in 36, and laparotomy in 5. Operative findings were mesenteric LAP in 4 and polyP in I.
\end{abstract}

CONCLUSION: PR is effective for the treatment of intussusception and recurrences. Delayed presentation reduces the success rate. In the event of failure, a lead point is usually encountered at laparotomy.

Keywords: Intussusception; pneumatic reduction; recurrent intussusception.

\section{INTRODUCTION}

Intussusception is the most common cause of bowel obstruction in children between the ages of 3 months and 3 years, and incidences in children between the ages of 5 and 9 months are on the rise. The classic triad of intussusception consists of colicky abdominal pain, palpable abdominal mass, and red



currant jelly stools. However, this triad is encountered in only $25-50 \%$ of cases. This can result in delays in diagnosis and treatment. Ultrasonography (USG) is the method most commonly used to diagnose intussusception. ${ }^{\left[{ }^{I]}\right.}$

Treatment options include enema reduction when appropriate, and should nonoperative methods prove unsuccessful, surgical intervention. Recently, the most commonly used method of treatment has been fluoroscopic or USG-guided pneumatic reduction (PR). It is known as a reliable approach based on the high rates of success and low rates of complication reported in several case series. In spite of this, there have been cases in which PR was unsuccessful, or intussusception recurred early on, following the PR, though these cases are rare. The present objective was to evaluate cases in which intussusception was unsuccessfully treated with PR in the present institution, as well as cases in which intussusception recurred following PR treatment. 


\section{MATERIALS AND METHODS}

Files of $40 \mathrm{I}$ patients who presented with intussusception and were treated with PR between 2003 and 2014 were retrospectively reviewed. Of the cases reviewed, 61 were included. In 20 of which, reductions could not be completed using the pneumatic method (Group I), and in $4 \mathrm{I}$ of which, intussusception recurred following successful reduction (Group 2). Patient age and gender, duration of symptoms, seasonal distribution, failure and recurrence rates, and underlying pathologies were evaluated.

All patients underwent the same standard procedures. Diagnosis was based on physical examination, upright direct abdominal radiography, and abdominal USG. USG was used to detect the presence of intussusception, intra-abdominal fluid, mesenteric lymphadenopathy (LAP) and pathological lead point, as well as to determine the length of the intussuscepted segment. Sufficient intravenous fluid replacement and a single dose of antibiotics were administered prior to the procedure. A nasogastric tube was inserted. As soon as the families gave consent, PR was performed.

All PR procedures were performed by a pediatric surgery and anesthesiology team under standard operating conditions with fluoroscopic guidance. Blood pressure, heart rate, and oxygen saturation were monitored. Sedation was achieved by administering a $0.1 \mathrm{mg} / \mathrm{kg}$ intravenous dose of Dormicum (midazolam). An insufflator bulb, a sphygmomanometer, and an I8-F Foley catheter were used during PR. Air was insufflated to a maximum pressure of $120 \mathrm{mmHg}$ via the Foley catheter, which was inserted into the rectum. When fluoroscopy demonstrated that the mass was gone and that air was passing into the small intestine, the procedure was considered successful and the operation was brought to a close. If the intussuscepted segment was not reduced, or perforation occurred during the procedure, the procedure was deemed unsuccessful and laparotomy was performed.

Re-intussusception was defined as the occurrence of colicky abdominal pain and the radiologic appearance of intussuscepted segment recurrence following an initial successful PR of the intussuscepted segment, either immediately or after a delay. In these patients, PR was repeated in the same manner as in primary intussusception cases. Laparotomy was performed if reduction could not be accomplished using the pneumatic method.

Statistical analysis was performed using chi-square test and Student's t-test. A p value of $<0.05$ was considered significant.

\section{RESULTS}

A total of $40 \mathrm{I}$ patients underwent PR during the study period. PR was unsuccessful in 20 of these cases. In 4 I cases, patients experienced at least I recurrent episode of intussusception.
Group I consisted of 20 cases (I5 male, 5 female) for whom reduction could not be completed using the pneumatic method. Rate of failed PR was $5 \%$. Mean age of this group was 14.2 months (range 2.5 months -6 years). Age distribution analysis demonstrated that 15 patients $(75 \%)$ were aged between 0 and I years, and 5 patients $(25 \%)$ were aged between I and 6 years. Mean symptom duration prior to presentation was 2.5 days (range $1-7$ days). Rectal bleeding was present in 7 cases. Intussusception was detected on USG in 16 cases. Average size of intussuscepted segment detected by USG was $7 \mathrm{~cm}$ (range 3-10 cm). Anechoic fluid was detected in the abdomens of 9 patients (45\%). Mesenteric lymphadenopathy (MLA) was observed in 7 patients. No additional pathological lead points were detected on USG (Table I).

Fifteen of the 20 patients in Group I underwent laparotomy due to failure to reduce the intussuscepted bowel segment. During laparotomy, additional pathologies were noted: mesenteric LAP and/or Peyer's patch hyperplasia in 13 cases, and Meckel's diverticulum in 2 cases. Five of the 20 patients underwent laparotomy after perforation occurred (Figure 1). Of these 5, mean age was 8 months (range: 6-9 months), and mean time to presentation was 3 days (range: $2-4$ days). Rectal bleeding was present in 3 cases. In I case, no intussusception had been detected on USG. Average size of intussuscepted segments detected on USG was $3 \mathrm{~cm}$ (range 3-6 cm). Anechoic fluid was detected in the abdomen in 4 cases $(80 \%)$, and mesenteric LAP was present in 3 cases. Underlying pathologies observed during laparotomy were Meckel's diverticulum in 3 cases and mesenteric LAP and/or Peyer's patch hyperplasia in 2. The properties of these cases of perforation were considered, and statistical analysis was performed (Table 2). Analysis demonstrated that in the cases of perforation, only the presence of intra-abdominal fluid on USG was statistically significant $(p<0.05)$. Anatomic location of intussusception in Group I was ileocolic in 18 cases, ileoileal in I case, and colocolic in I case.

Group 2 consisted of 4 I patients ( 33 male, 8 female) who

Table I. Patient demographic specifications and radiological findings in Group I $(n=20)$

\begin{tabular}{ll} 
Age & 1.5 years \\
& $(2.5$ mo-6 yrs $)$ \\
Male gender & $15(75 \%)$ \\
Rectal bleeding & $7(35 \%)$ \\
Duration of symptoms & 2.5 days $(1-7$ days $)$ \\
Intussuscepted segment on USG & $16(80 \%)$ \\
Size of intussuscepted segment on USG & $7 \mathrm{~cm}(3-10 \mathrm{~cm})$ \\
Mesenteric lympadenopathy (MLA) on USG & $7(35 \%)$ \\
Fluid on USG & $9(45 \%)$ \\
\hline
\end{tabular}

MLA: Mesenteric lymphadenopathy; USG: Ultrasonography. 




Figure 1. Surgical management and operative findings in Group 1.

experienced re-intussusception. Rate of re-intussusception was $10.2 \%$. Mean age of this group was 20 months (range: 3 months -6 years). Analysis of age distribution demonstrated that 26 patients $(63 \%)$ were aged between 0 and I years, II patients $(27 \%)$ were aged between I and 3 years, and 4 patients $(10 \%)$ were aged between 3 and 6 years. Time to appearance of re-intussusception was within the first 24 hours in 21 cases (5l\%). Twelve of these patients (29\%) were younger than I year. Re-intussusception occurred in spring in 20 cases (49\%), in winter in 10 cases $(24 \%)$, in summer in 9 cases $(22 \%)$, and in autumn in 2 cases $(5 \%)$.

No intussusception was detected on USG examination in 5 cases in Group 2. Mean size of intussuscepted segments detected with USG was $5 \mathrm{~cm}$ (range: $2-12 \mathrm{~cm}$ ). Mesenteric LAP was present in 30 cases (73\%). Anechoic fluid was detected in the abdomen in 12 cases. No additional pathological lead points were detected on USG.

Five Group 2 patients experienced more than I recurrence

Table 2. Properties and statistical analyis of Group I

\begin{tabular}{lc}
\hline Variable & p \\
\hline Age & $>0.05$ \\
Gender & $=0.29$ \\
MLA on USG & $=0.78$ \\
Fluid on USG & $=0.00982^{* *}$ \\
Size of intussuscepted segment on USG & $>0.05$ \\
\hline
\end{tabular}

"Statistical significance; MLA: Mesenteric lymphadenopathy; USG: Ultrasonography. of intussusception. Of the 4I Group 2 patients, recurrent intussusception ( $R I)$ was treated by $P R$ in 36 , and laparotomy and manual reduction in 5 (Figure 2). In 2 of the 5 cases, no intussuscepted segment was detected on USG examination. Anechoic fluid was detected in the abdomen in 3 cases. No additional pathological lead points were detected on USG in these patients. Operative findings were mesenteric LAP and/or Peyer's patch hyperplasia in 4 patients and polyp in $\mathrm{I}$. Pathologic examination of the polyp was consistent with juvenile polyps. Anatomic location was ileocolic in 3 cases and ileoileal in I. The patient with ileoileal intussusception was the only to undergo laparotomy twice. No statistically significant difference was found in age, gender, presence of intraabdominal fluid on ultrasound, or size of intussuscepted segment in Group 2 patients who underwent surgery ( $p>0.05)$.

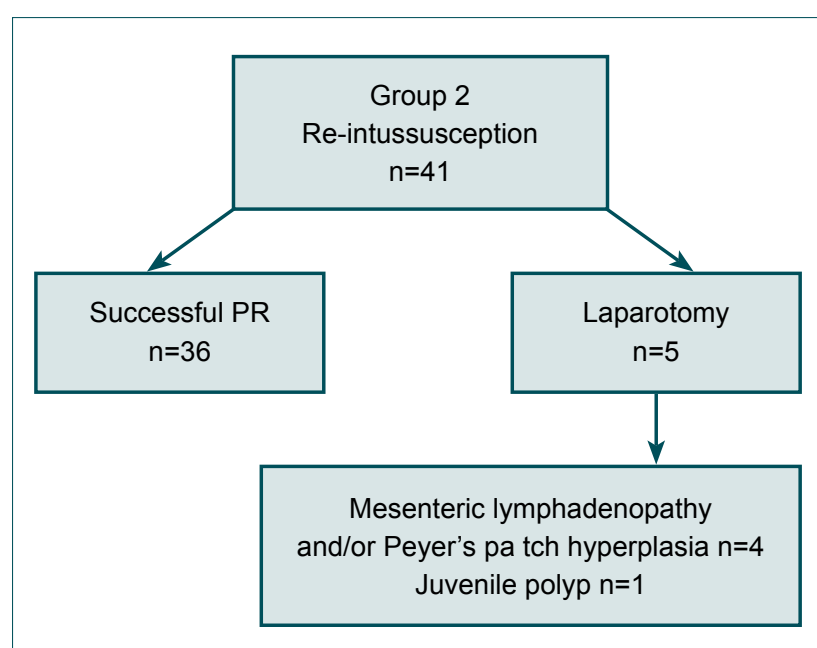

Figure 2. Management and operative findings in Group 2. 
When data of Groups I and 2 were statistically compared, no significant differences were found regarding age, gender, presence of intra-abdominal fluid on USG, or presence of mesenteric LAP.

\section{DISCUSSION}

Intussusception is the most commonly encountered cause of bowel obstruction in childhood, with a reported incidence of 56/100000. It most frequently occurs in patients aged between 3 months and 3 years. The classic triad of intussusception symptoms, which includes colicky abdominal pain, red currant jelly stools, and palpable abdominal mass, are encountered in only $25-50 \%$ of cases. The potential variety of symptoms can lead to difficulty in identification and diagnosis, and thus delays in therapy.

The first-line treatment of intussusception, if no signs of perforation or peritonitis are present, is enema reduction, a nonoperative method. Surgical intervention is performed on patients with signs of peritonitis upon initial presentation, and in cases in which enema reduction was not successful. Enema reduction is performed in a hydrostatic or a pneumatic manner, and under guidance of fluoroscopy or USG. Various studies have reported success rates of $40-95 \%$ for nonoperative treatments. Hydrostatic and pneumatic reductions have been compared in numerous studies, and higher rates of success and lower mortality rates have been reported with the use of pneumatic reductions. ${ }^{[1-4]}$ The success rate of PR was found to be $88-95 \% .^{[3,5]}$ The pneumatic method has other advantages, as well. It may be used in the diagnosis and treatment of intussusception, and it carries a lower radiation risk, compared to hydrostatic reduction. Moreover, in the event of perforation, there will be less peritoneal spread, corresponding to a lower rate of morbidity and mortality. ${ }^{[5]}$ For these reasons, many publications recommend PR as a firstline treatment. ${ }^{[3]}$ The open surgery method was the former first-line treatment at the present institution, but PR has increasingly taken its place, particularly over the past decade, ${ }^{[6]}$ and the PR success rate is $95 \%$.

Two limiting factors must be discussed with regard to PR: failure to identify lead points and pseudo reductions. ${ }^{[5]}$ In the present series, a total of 25 laparotomies were performed, and pathological lead points were identified in 6 of these patients (Meckel's diverticulum in 5 cases, juvenile polyp in I case). Perforation was observed during the PR procedure in 3 of the 5 patients with Meckel's diverticulum. The complications of $\mathrm{PR}$ are failed reduction, perforation, and in rare cases tension pneumoperitoneum and RI. ${ }^{[7-9]}$

Reasons for failure of nonoperative methods have been questioned in a number of studies. Success rates may vary based on patient-related factors or factors relating to the team performing the procedure. Patient-related factors evaluated were lateness of presentation, age of patient, dehydration, lethargy, the presence of bloody stools, and the length of the intussuscepted segment. It has been determined by a majority of authors that the factors increasing the probability of surgical intervention were use of hydrostatic enema, failure of the first attempt at enema reduction, bloody stools, symptoms that had lasted more than 24-48 hours, age younger than I year, and a long length of intussuscepted bowel. ${ }^{[1,10]}$ In the present series, the rate of unsuccessful reduction was $5 \%$, and $75 \%$ of those patients were younger than I year of age. However, this was not found to be statistically significant. In contrast to these studies, Tareen found no relationship between failure in PR and length of symptoms, and reported a PR success rate of $88 \%$, even in recurrent cases. ${ }^{[3]}$ At a different center, Curtis et al. reported that patients presenting following unsuccessful reduction showed similar PR results to primary patients. ${ }^{[I]}$ In the present study, the average time from onset of symptoms was 60 hours in the failed reduction group, suggesting that time alone should not be a contraindication for PR, but must be evaluated together with other factors.

The success rate of PR demonstrates a correlation with USG data in the diagnostic stage. USG indications of thinning of the intestinal walls, lead points, or fluid (either between bowel loops or free in the abdomen) increases the probability of need for surgical intervention. Presence of these findings may be associated with failed reduction and occurrence of perforation. Presence of fluid between bowel loops has been shown to result in a fourfold reduction in the success rate of PR. Nevertheless, it is recommended in the literature that USG findings be evaluated with other clinical findings. In the present study, it was particularly noteworthy that free intraabdominal fluid was found on USG in $80 \%$ of cases that included perforation. ${ }^{[1,5,12]}$ No correlation of USG signs of intraabdominal fluid and perforation were presently determined.

Another factor that may affect the success of PR is the experience of the team performing the procedure and the techniques used. This procedure is generally carried out by a pediatric radiology team. A pediatric anesthesiology and surgical team must also stand by at the ready in the event of an unsuccessful reduction or the development of other complications. PR can be performed under guidance of USG or fluoroscopy. USG-guided PR is a non-invasive procedure with a high success rate. The drawback is that it requires a high level of experience with USG. The most frequent point of criticism in fluoroscopic-guided PR is the exposure to radiation. PR has been shown to possess a lower radiation risk, compared to reduction with barium enema. ${ }^{[3]}$ As experience with PR increases, the rate of complications decreases, procedure time is shortened, and consequently, the exposure to radiation decreases. ${ }^{[5,13]} \mathrm{PR}$ performed by inexperienced teams is reported to have lower success rates and higher rates of complication. ${ }^{[5]}$ PR procedures at the present clinic are performed under standard operating conditions with fluoroscopic guidance. An anesthesiology team performs the 
sedation, and PR is performed by a pediatric surgery team. This eliminates the need for a pediatric radiologist to be at the clinic around the clock, and allows for fast intervention in the event of complications. Moreover, the high success rate of the present series is thought to be due to the same team performing this procedure, and the high level of experience they have obtained in doing so.

The most feared complication of PR is perforation, and consequent tension pneumoperitoneum. Perforation rates of $0.1-3 \%$ have been reported in various case series. ${ }^{[5,9,14,15]}$ In the present series, that rate was $1.2 \%$. It has been reported that intracolonic pressure can be safely maintained at 80-130 $\mathrm{mmHg}{ }^{[8,14,16]}$ The area of perforation in PR is smaller, generally does not increase in size, and results in less fecal spread, compared to hydrostatic reduction. ${ }^{[16]}$ The rate of complications such as ischemic bowel, perforation, and peritonitis particularly increases in cases involving late diagnosis, general poor health, and a history of bloody stools. Perforation is seen more often in patients younger than I year. ${ }^{[3]}$ The presence of pathological lead points increases the probability of perforation during $P R{ }^{\left[{ }^{[}\right]}$In the literature, $20 \%$ of patients undergoing open surgery demonstrated pathological lead points such as Meckel's diverticulum, lymphoma, intestinal polyps, and adenocarcinoma. Patients older than 5 years of age were found to have a higher probability of underlying pathology. ${ }^{[1,15]}$ In the present series, all 5 patients who experienced perforation were under I year of age, and a pathological lead point was present in $60 \%$. Average time to presentation was 3 days. This suggests that late presentation increases complications, which is consistent with the literature.

The use of sedation during the PR procedure remains controversial. In an experimental study by Shiels, the performance of the Valsalva maneuver during PR was reported to protect against perforation, but deep sedation prevents the patient from performing this maneuver. ${ }^{[16]}$ On the other hand, llivitzki et al. has stated that the use of propofol provides sedation, reduces the dose of radiation exposure by shortening the procedure, and makes the entire procedure more comfortable for children and families. ${ }^{[17]}$ At the present clinic, the anesthesiology team administered intravenous midazolam for sedation during PR to all patients. When the high rate of success and the low rate of perforation in the present series are considered, it does not appear that the use of sedation is associated with the development of perforation.

Incidence of $\mathrm{RI}$ following enema reduction has been reported between $8-15 \% .^{[7,14,15]}$ In the present study, this rate was $10.2 \%$. In the work of Niramis et al., it was reported that $68 \%$ of RI patients experienced the initial episode younger than I year of age, and $70 \%$ of recurrences occurred in the 6 months following the initial episode. In cases of RI, it was noted that patients were brought to the hospital earlier, due to earlier symptom recognition by families. Niramis et al. also reported that the rate of pathological lead point presence was 3 times higher in cases of RI. ${ }^{[7]}$ Of the present cases of RI, 65\% were under I year of age, $42 \%$ occurred within the first 24 hours after PR, and they were associated with a high rate (75\%) of mesenteric LAP on USG. In this group, 4 of the 5 patients (80\%) who underwent laparotomy exhibited pathological lead points. Other studies have shown that PR can be safely performed, even in the presence of a pathological lead point, but that in these patients the incidence of RI was higher. The relationship between recurrence and surgical intervention is controversial. For patients older than 2 years of age at the first episode, for patients in which the first treatment method used was reduction enema, and for patients suspected of having pathological lead points, surgical intervention is recommended. ${ }^{[7,18]}$

\section{Conclusion}

$P R$ is an effective and safe method in the treatment of intussusception. Late presentation and additional underlying pathologies reduce the success of the procedure and increase the rate of complications. The presence of intra-abdominal fluid on USG should be considered a strong indication of the possibility of perforation. Nevertheless, patients should be evaluated by taking all other factors into consideration. Prior failed intervention, the existence of long-lasting symptoms, and re-intussusception should not provide any obstacle to attempting PR, particularly when an experienced pediatric radiologist, and an experienced pediatric surgery and anesthesiology team are present.

\section{Conflict of interest: None declared.}

\section{REFERENCES}

1. Fallon SC, Lopez ME, Zhang W, Brandt ML, Wesson DE, Lee TC, et al. Risk factors for sur-gery in pediatric intussusception in the era of pneumatic reduction. J Pediatr Surg 2013;48:1032-6. Crossref

2. Beres AL, Baird R. An institutional analysis and systematic review with meta-analysis of pneumatic versus hydrostatic reduction for pediatric intussusception. Surgery 2013;154:328-34. Crossref

3. Tareen F, Ryan S, Avanzini S, Pena V, Mc Laughlin D, Puri P. Does the length of the history influence the outcome of pneumatic reduction of intussusception in children? Pediatr Surg Int. 2011;27:587-9. Crossref

4. Sonmez K, Turkyilmaz Z, Demirogullari B, Karabulut R, Kale N, Basaklar AC. Intussuscep-tion in children: experience with 105 patients in a department of paediatric surgery, Turkey. S Afr J Surg 2012;50:37-9.

5. Mensah YB, Glover-Addy H, Etwire V, Twum MB, Asiamah S, Appeadu-Mensah W, et al. Pneumatic reduction of intussusception in children at Korle Bu Teaching Hospital: an initial ex-perience. Afr J Paediatr Surg 2011;8:176-81. Crossref

6. Eliçevik M, Özcan R, Emre Ş, İlçe Z, Tekant GT, Sarımurat N, et al. A rapid review of a very well known: Intussusception. Cerrahpasa J Med 2006;37:41-4.

7. Niramis R, Watanatittan S, Kruatrachue A, Anuntkosol M, Buranakitjaroen V, Rattanasuwan T, et al. Management of recurrent intussusception: nonoperative or operative reduction? J Pediatr Surg 2010;45:2175-80.

8. Ryan ML, Fields JM, Sola JE, Neville HL. Portal venous gas and cardiopulmonary arrest dur-ing pneumatic reduction of an ileocolic intussus- 
ception. J Pediatr Surg 2011;46:5-8. Crossref

9. Fallon SC, Kim ES, Naik-Mathuria BJ, Nuchtern JG, Cassady CI, Rodriguez JR. Needle de-compression to avoid tension pneumoperitoneum and hemodynamic compromise after pneumat-ic reduction of pediatric intussusception. Pediatr Radiol 2013;43:662-7. Crossref

10. Fike FB, Mortellaro VE, Holcomb GW 3rd, St Peter SD. Predictors of failed enema reduc-tion in childhood intussusception. J Pediatr Surg 2012;47:925-7. Crossref

11. Curtis JL, Gutierrez IM, Kirk SR, Gollin G. Failure of enema reduction for ileocolic intus-susception at a referring hospital does not preclude repeat attempts at a children's hospital.J Pe-diatr Surg 2010;45(6):1178-81.

12. Gartner RD, Levin TL, Borenstein SH, Han BK, Blumfield E, Murphy $\mathrm{R}$, et al. Interloop fluid in intussusception: what is its significance? Pediatr Radiol 2011;41:727-31. Crossref

13. Cullmann JL, Heverhagen JT, Puig S. Radiation dose in pneumatic reduction of ileo-colic intussusceptions--results from a single-institution study. Pediatr Radiol 2015;45:675-7. Crossref

14. Cankorkmaz L, Köylüoğlu G, Arslan MS, Güney C. Our childhood cases with intussuscep-tion and pneumatic reduction. [Article in Turkish] Ulus Travma Acil Cerrahi Derg 2010;16:363-6.

15. Feltis AB, Schmeling DJ. Intussusception. In: Ziegler M, Azizkhan RG, Von Allmen D, We-ber TR, editors. Operative Pediatric Surgery, 2th ed. McGraw-Hill; 2014. p. 592-6.

16. Shiels WE 2nd1, Kirks DR, Keller GL, Ryckman FR, Daugherty CC, Specker BL, et al. John Caffey Award. Colonic perforation by air and liquid enemas: comparison study in young pigs. AJR Am J Roentgenol 1993;160:931-5. Crossref

17. Ilivitzki A, Shtark LG, Arish K, Engel A. Deep sedation during pneumatic reduction of in-tussusception. Pediatr Radiol 2012;42:562-5.

18. Kaiser AD, Applegate KE, Ladd HP. Current success in the treatment of intussusception in children. Surgery 2007;142:469-77. Crossref

\section{ORİIINAL ÇALIŞMA - ÖZET}

\section{İnvajinasyonda başarısız pnömatik redüksiyon ve reinvajinasyon olgularının incelenmesi \\ Dr. Rahşan Özcan, ${ }^{1}$ Dr. Mirzaman Hüseynov, ${ }^{1}$ Dr. Şenol Emre, ${ }^{1}$ Dr. Çiğdem Tütüncü,, ${ }^{2}$ Dr. Hayriye Ertem Vehid, ${ }^{3}$ Dr. Sergülen Dervişoğlu, ${ }^{4}$ Dr. İbrahim Adaletli, ${ }^{5}$ Dr. Sinan Celayir, ${ }^{1}$ Dr. Gonca Tekant ${ }^{1}$}

\footnotetext{
${ }^{1}$ İstanbul Üniversitesi Cerrahpaşa Tıp Fakültesi, Çocuk Cerrahisi Anabilim Dalı, İ $\square$ stanbul

2'̇stanbul Üniversitesi Cerrahpaşa Tıp Fakültesi, Anesteziyoloji Anabilim Dalı, İ $\square$ stanbul

${ }^{3}$ Istanbul Üniversitesi Cerrahpaşa Tıp Fakültesi, Biyoistatistik Anabilim Dalı, İstanbul

${ }^{4}$ İstanbul Üniversitesi Cerrahpaşa Tıp Fakültesi, Patoloji Anabilim Dalı, İstanbul

${ }^{5}$ İstanbul Üniversitesi Cerrahpaşa Tıp Fakültesi, Radyoloji Anabilim Dalı, İstanbul
}

AMAÇ: İnvajinasyon tedavisinde pnömatik redüksiyon (PR) ile başarısız olunan olgular ve PR ile tedavi sonrası tekrar invajinasyon gelişen olguların değerlendirilmesidir.

GEREÇ VE YÖNTEM: 2003-20I4 yılları arasında invajinasyon nedeni ile tedavi edilen 40I olgunun kayıtları geriye dönük olarak incelendi. Bu çalışmaya alınan 6 I olgunun 20'si (Grup I) başarısız PR ve 4l'i (Grup 2) başarılı redüksiyon sonrası tekrar invajinasyon gelişen olgulardı. Uygulanan tedavi ve sonuçları incelendi.

BULGULAR: Grup I'de (yaş ortalaması: 14.2 ay) operasyon endikasyonu I5'inde başarısız PR ve beşinde PR sırasında perforasyondu. Bu beş olgunun tamamı bir yaş altındaydı ve ortalama başvuru zamanı üç gün (2-4 gün) idi. Laparatomide ek patoloji olarak; olguların I5'inde mezenterik lenfadenopati ve/veya peyer plak hiperplazisi, beşinde meckel divertikülü saptandı. Grup 2'de (yaş ortalaması: 20 ay) reinvajinasyon en sık ilk 24 saatte $(n=21)$ görüldü. Kırk bir olgunun 36'sında reinvajinasyon PR ile tedavi edildi, beşine laparotomi yapıldı. Operasyon bulguları dördünde mezenterik lenfadenopati ve birinde polip idi.

TARTIŞMA: Pnömatik redüksiyon invajinasyonu ve nüksetme tedavisinde etkili ve güvenilir bir yöntemdir. Geç başvuru pnömatik redüksiyon başarısını azaltmaktadır. Başarııız PR'de laparotomide genellikle lead point ile karşılaşııı.

Anahtar sözcükler: İnvajinasyon; pnömatik redüksiyon; rekürren invajinasyon.

Ulus Travma Acil Cerrahi Derg 20।6;22(3):259-264 doi: 10.5505/tjtes.20।6.7985 | 